\title{
The Upsurge of Oil Theft and Illegal Bunkering in the Niger Delta Region of Nigeria: Is There a Way Out?
}

\section{Odalonu Happy Boris}

\author{
Centre for Population and Environmental Development, Benin City, Edo State, Nigeria
}

Email: boris2nice@gmail.com

\section{Doi:10.5901/mjss.2015.v6n3s2p563}

\begin{abstract}
This paper examines the rising cases of oil theft in the Niger Delta region of Nigeria which has negatively impacted on the Nigerian economy. This is because Nigerian state solely depend oil generated revenues for her economic survival. The aim of this study is to critically examine the methods, actors, causes, impacts of oil theft and the measures adopted by Nigerian governments to combat oil theft. The location of the study is the Niger Delta region and the study was timed within the period of 2009-2014. Secondary data were generated for the study, while content analysis was used for data interpretation and analysis. The study revealed that different individuals and groups were involved in oil theft and illegal bunkering activities. The study further proved that persistence oil theft in the Niger Delta is due to the enthroned corruption by Nigerian elites, high level of youth unemployment, ineffective and corrupt law enforcement agencies and international crime collaborations. The study also revealed that successive Nigerian governments have made attempts to curb the menace by the establishment of a special security outfit, militarization of the Niger Delta region and granting of amnesty to Niger Delta militants but the upsurge of oil theft in recent times clearly indicates that success has not been achieved, hence some recommendations were proffered to put an end to oil theft in the Niger Delta region.
\end{abstract}

Keywords: Actors, Crude Oil, Niger Delta, Nigerian Economy, Oil Theft.

\section{Introduction}

Oil is unarguably the lifeblood of modern economy and it has now become the most essential commodity in the world. Hence, no nation today can survive without oil that is why Smil (2008) describes it as the "lifeblood of modern world", adding that, "without oil, there would be no globalization, no plastic, little transport, and a worldwide landscape that few would recognize". Yergin (2008) also calls it "the world's most important resource". In recognition of the significance of oil, Feyide (1986) aptly stated that:

\begin{abstract}
"Oil is raw material as well as a convenient and effective source of energy. In the form of energy it increases man's capacity to get work done. As a raw material it provides the feedback for the fasts expanding industry in the world-the petrochemical industry...All over the world lives of people are affected and the destinies of nations are probably determined by the results of oil industry operations. Oil keeps the factories of the industrialized countries working and provides the revenues which enable oil exporters to execute ambitious national and economic development plans. Those developing countries that have no oil are faced with a grim struggle for survival: if they lose they are relegated to the "fourth world" the march of progress would be retarded and life itself would become unbearable if the world was deprived of oil. That is why oil has become the concern of governments, a vital ingredient of their polices and a crucial factor in their political and diplomatic strategies".
\end{abstract}

Nigeria, being a mono-economy nation largely depends on the oil sector for its economic survival. The Nigerian economy is dependent on the exploitation of crude oil and the nation's future is very much tied to the commodity (Okere, 2013). Indeed, oil and gas resources from Niger Delta region accounts for over $90 \%$ of Nigerian export and foreign exchange earnings, and over 70\% of total Nigerian revenue (Ekuerhare, 2002). This informs Wilson (2012) to state that the increase or otherwise in crude oil production affects directly the revenue base and development programmes of Nigerian state. Oil is now the mainstay of Nigeria's economy. It is the country's major export, fetching millions of petrodollars to the country each day. Sadly, that same resource is being savagely stolen in copious quantities on daily basis (Adeboboye, 2013).

The upsurge of oil theft in the Niger Delta region of Nigeria in recent times is alarming. Presently, Nigeria is losing over 300,000 barrels of crude oil per day to oil theft, pipeline vandalism and related criminal vices in the country's oil 
sector (Akpan 2013; Olusola, 2013; Odemwingie and Nda-Isaiah, 2013; Okere, 2013). Despite the efforts of the Federal government to curtail the illegal diversion of oil in the Niger Delta by increasing its security spending in recent years and devoting millions of naira annually to hire private security firms as well as equipping men and officers of the Nigeria Security and Civil Defence Corps (NSCDC), incessant destruction of pipelines and other oil facilities across the country as well as trade in stolen oil by criminal cartels with international connections have continued unabated (Ugwuanyi, 2013; Mernyi, 2014). This shows that, the huge investments of public funds on the safety of oil facilities have not yielded the required results.

Consequently, the Nigerian economy is in a precarious situation. She is facing an economic emergency unprecedented among the oil producers of the world and something urgent needs to be done to reverse the ugly trend. For instance, Nigeria has been tagged the most country plagued by oil theft among her contemporaries of Indonesia, Russia, Iraq and Mexico. Statistics of oil theft among these major oil-producing countries shows that Nigeria is losing as much as 400,000 barrels of oil per day which equates to losses of US\$1.7-billion a month (Ameh , 2013; Dalby, 2014). This is huge loss compared to a total theft of 5,000 to 10,000 barrels per day and just 2,000 to 3,000 barrels per day in Mexico and Indonesia respectively (Dalby, 2014). Thus, oil theft and illegal bunkering activities in the Niger Delta pose a challenge that threatens the very foundation of the oil industry, and by extension, the Nigerian economy (Garuba, 2012). Why has there be persistent increase of oil theft activities in the Niger Delta in recent times? Who are the perpetrators of oil theft? What are the implications of oil theft in the Niger Delta? What has the government done to put an end to the menace? These are myriad of questions that need to be explored.

\section{Purpose of the Study}

The purpose of this paper is to critically examine the phenomenon of oil theft, nature and operational mechanism of oil theft, economic and environmental impacts of oil theft on the Niger Delta, International Oil Companies (IOCs) as well as Nigerian State. Specifically this study sought to unravel:

- Oil theft and illegal bunkering in the Niger Delta

- The operational mechanisms of oil theft in the Niger Delta

- The actors of illegal oil bunkering and oil theft in the Niger Delta

- Factors engendering oil theft in the Niger Delta

- The socio-economic and environmental impacts of oil theft

- The efforts of Nigerian Government to curb oil theft

- Measures to combat oil thieves

\section{Scope and Methodology}

This study essentially focused on the activities of oil theft in the Niger Delta region of Nigeria from 2009 to 2014 . This study is qualitative and exploratory in approach. To achieve the objectives of this study, secondary data formed the basis of data collection, interpretation and analysis. Data was collected through a comprehensive review of relevant literature on the subject of inquiry. The thrust of analysis was systematically prosecuted under select themes and sub-themes designed to address the salient aspects of the paper's objective.

\section{Niger Delta Region}

Conceptualizing the Niger Delta region has elicited several viewpoints from scholars. The debate over the definition of the region has led to several terminologies such as the "Oil Rivers Protectorate", "Core Niger Delta", "Political Niger Delta", "South-South Geo-Political Zone" and "Oil Producing Areas" to describe the Niger Delta (Isoun, 2001; Nwachukwu, 2008; Akpabio and Akpan, 2010). Historically and cartographically, Niger Delta region consists of present day Bayelsa, Delta and Rivers states. In 2000, Obasanjo's regime expanded its definition to include:, Abia State, Akwa Ibom State, Cross River State, , Edo State, Imo State and Ondo State. Thus, the Niger Delta region consists of nine oil producing states. Arguably, Okoli (2013) noted that the core Niger Delta states are Bayelsa, Delta and Rivers States while the peripheral Niger Delta states are Abia, Akwa-Ibom, Cross Rivers, Edo, Imo and Ondo States. This collaborate with the view of Obi and Rustad (2011) that three states namely, Rivers, Bayelsa and Delta states, make up the Niger Delta in terms of the quantity of oil production and petroviolence.

As it stands, Niger Delta is a home of over 31 million people, made up of multiethnic nationalities, such as Ikwerre, 
Ogoni, ljaw, Ogba, Ahoada, Urhobo, Itsekiri, Efik, Ibibio, Annang, Oron, Isoko, Ukwuani, kalabari, Ekwere, etc., speaking about 250 different dialects (Wikipedia, 2013; Okurebia and Daniel, 2014). The region occupies a total area of about 75, $000 \mathrm{~km}$ and makes up 7.5\% of Nigeria's land mass which cut across over 800 oil producing communities with an extension network of over 900 oil producing wells and several petroleum production related facilities (Young, 2012; Osuji and Onojake, 2013; wikipedia, 2013; Okurebia and Daniel, 2014). The region holds 95\% of Nigerian oil reserves which account for $90 \%$ of Nigerian government revenue and 95\% of its export receipts (Ikelegbe, 2005; Ikein, 2009)). Despite these impressive figures, the region is one of the poorest and least developed in Nigeria. Most of its inhabitants lack basic amenities such as the provision of electricity, potable water, and health facilities. Besides, the people suffer enormous negative externalities engendered by oil extraction and production including oil spills and gas flaring which destroy the local livelihoods (Ojo, 2010). This environmental degradation and food insecurity had predisposed the local people to militancy and agitation for equitable oil revenue allocation from the lopsided Nigerian federation and insistence on Corporate Social Responsibility from the oil companies (Tonwe and Aghedo, 2013).

\title{
5. Oil Theft and Illegal Bunkering
}

Oil theft, also known as illegal bunkering, is the act of hacking into pipelines to steal crude which is later refined or sold abroad (Ugwuanyi, 2013). It is an illicit trade that involves the theft of crude oil and its derivative products through a variety of mechanisms. Asuni (2009) refers to oil theft as oil taken from pipelines or flow stations, as well as extra crude oil added to legitimate cargo that is not accounted for. In support of the above positions, Obasi (2011) asserts that "illegal oil bunkering" as used in Nigeria is a generic term encompassing not only unauthorized loading of ships but also all acts involving the theft, diversion and smuggling of oil". Ikelegbe (2005) noted that:

\begin{abstract}
"There is a large scale illegal local and international trading on crude oil. This has grown from a few amateurs in the 1980s who utilized crude methods to extract crude from pipelines to a very sophisticated industry which uses advanced technologies to tap crude and sophisticated communications equipment to navigate through the maze of hundreds of creeks, rivers and rivulets. The oil theft syndicates have also graduated from boats and barges to ships and large oil tankers in the high seas. The stealing and smuggling of crude has become very extensive and large scale since the late 1990s".
\end{abstract}

The import of the foregoing is that crude oil theft is any activity relating to the theft or sabotage of crude oil, facilities or installations in form of illegal bunkering, pipeline vandalism, fuel scooping, illegal refining, etc. Illegal oil bunkering is the most commonly known form of oil theft and it involves direct tapping of oil. Though oil bunkering is a necessity for maritime shipping within the maritime sector, it becomes an illegal oil bunkering when it is carried out without requisite statutory licenses or valid documents, or in violation of the Nigerian maritime sector.

\section{The Operational Mechanisms of Oil Theft in the Niger Delta}

Oil theft is carried out at different levels and quantities; hence there are various methods in which oil theft operations are carried out in the Niger Delta. The most popular method for stealing the crude oil is to puncture the pipeline conveying the product from one point to the other and tap it at the point where it had been punctured or ruptured (Adegbite, 2013). According to Asuni (2009); Katsouris and Sayne (2013) there are three operational methods of illegal bunkering and oil theft in the Niger Delta. These are: (1) a minor and small-scale pilfering of condensate and petroleum product destined local market; (2) direct hacking into pipelines or tapping with a hose from wellhead through practical removal of the 'Christmas tree'; and (3) excess lifting of crude oil beyond the licensed amount, using forged bills of lading. While the first is less significant in that it is conducted by local people who hide under the cover of violence in the Niger Delta region, the second category brings more technical sophistication into the business with the stolen product placed in small barges and taken straight into the sea where it is loaded into larger barges (mother ships) in return for money and weapons used to fuel violence, while the last category speaks solely about a spoilt system facilitated by official corruption in that it involves the use of forged bills of lading, "issued by a carrier to a shipper, listing and acknowledging receipt of goods for transport and specifying terms of delivery."

\section{The Actors of Oil Theft in the Niger Delta}

Oil theft in the Niger Delta is now on an industrial scale and involves commodity traders, international criminals and a whole network of people (Olateju, 2013; Vidal, 2013; Ogunmade \& Uwaezuoke, 2013). The activities of oil theft at 
industrial scale are clearly of a sophisticated organization. There are large international syndicates involved in this operation, which also handle the money laundering for the international players (Asuni, 2009; Katsouris and Sayne, 2013). While Niger Delta youth may handle the local tapping and loading, international players from Eastern Europe, Russia, Austrialia, Lebanon, the Netherlands, and France all play roles in financing, transporting, and laundering the money associated with oil theft. One money trail followed a path from Senegal and Cote d'Ivoire through French banks and French credit agencies to Syria and Lebanon (Coventry Cathedral, 2009).

Presently oil theft in the Niger Delta involves a convoluted and complex web of relationship spanning all levels of the society- involving diverse relationship. These relationship are alleged to include highly connected people in and outside government (members of the executive and legislative arms of government), oil companies including (Nigeria National Petroleum Corporation, NNPC) businessmen, retired and serving military officers, and militants among others (Ayanruoh, 2013). Similarly, Asuni (2009) identified the main players involved in the illegal oil bunkering business at its various levels:

\begin{abstract}
"At the local level, Niger Delta youth and community leaders play the leading. As one moves up the network to the senior echelons, members of the Nigerian military, oil Company and NNPC employees, top politicians and retired military officers predominate. At an international level, countries from Eastern Europe, Russia, Australia, Lebanon, Netherlands, France, Senegal, Cote d'Ivoire etc., are all involved. The crews of two bunkering ships- one filipino, another Ghanaian were recently arrested in Nigeria and shed some light on this shadowy network"
\end{abstract}

In support of this position, Olateju (2013) stressed that:

"Let no one be deceived. The rich, powerful and connected are Nigeria's oil Mafiosi. Oil theft is a big criminal ring with sophisticated organization and international network..where will poor people get the millions to buy or rent vessels, bribe customs and get military cover for their operations? Oil theft is not for the poor, it is an extensive racket involving military, security apparatchiks, politicians, dubious industrial moguls and oil companies---You don't have to snoop around the communities to find tell tale signs of oil theft. They are all too impossible to miss; everything is flung out in the open. The communities themselves are complicit in the trade as it provided employment for them".

Arguably, there has been alleged complicity of oil theft in the Niger Delta by the security forces. Signs of alleged participation by security forces in oil theft include; Brigadier General, then, a commander in the Joint Task Force (JTF) that patrol parts of the delta was relieved of his post in March, 2006, owing to alleged involvement with illegal bunkering, over a dozen retired military officers including a rear admiral were arrested on suspicion of oil theft during the (2000s) all were later freed without charged, claims to have observed rank-and-file JTF officers standing guard at illegal tap points and providing armed escort to ships loaded with stolen crude (Katsouris and Sayne, 2013). Multinational Oil Company personnel have been alleged to be involved in oil theft. For instance, two suspected surveillance workers of one of the oil companies were arrested on November 19, 2012, for breaking and tapping crude oil from Shell Petroleum Development Company (SPDC) pipeline located at Kporgho in Gokana Local Government Area of Rivers State by soldiers of the Joint Task Force (JTF) (Izeze, 2013).

Drawing from the above, the activities of oil theft in the Niger Delta region of Nigeria are clearly a sophisticated organization. It involves different personalities from within and outside Nigeria.

\title{
8. Factors Engendering Oil Theft in the Niger Delta
}

There are various factors engendering the persistent thriving oil theft activities in the Niger Delta. According to Adegbite (2013) there are many perceived reasons for engaging in crude oil theft. The reasons vary from the mundane to the absurd. They include (a) poverty; (b) ignorance; (c) greed; (d) lack of respect for national economic survival; (e) get rich syndrome; (f) lack of gainful employment ; $(\mathrm{g})$ exploiting the loopholes in the criminal justice system to circumvent the law ; (h) evolving culture of impunity from the wrong perception that some people are above the law; (i) weak institutional structure to checkmate criminals; (j) malice; and (k) bad governance (corruption, incompetency), just to mention a few. Igbuku (2014) also identified some of the underlying causes of this scourge to include poverty, community-industry expectation mismatch, corruption, unemployment, ineffective law enforcement and poor governance. He adds that high unemployment, for instance has created a huge population of idle young people who are easily lured to oil related crimes. These crimes in turn are reinforced in the absence of clear deterrent measures, arising from the non-prosecution of alleged perpetrator. In the same vein, Mernyi (2014) stated that:

'Some experts in the oil sector are in consensus that the persistence upsurge of illegal bunkering in the Niger Delta is 
due to high levels of youth unemployment, armed ethnic militia, ineffective and corrupt law enforcement agencies and other state actors who are often part of an international syndicate. They argued that oil theft and pipeline vandalism continued to thrive in Nigeria inspite of government's efforts because of some vested interest of powerful persons involved in the business and the lack of political will to deal with it. They believed that the Nigerian leaders especially the political class is benefiting from illegal oil bunkering hence lack political will to confront it. They further argued that if the leaders are not benefiting directly or indirectly, they must have come up with measures or legislation to stop the menace"

As noted by Brock (2012), due to years of neglect, marginalization and underdevelopment of the Niger Delta by the Federal Government and the Multinational Oil Companies (MNCs) operating in the region, rings of organizes criminal groups, called "oil bunkerers" in our local parlance, has evolved in the creeks and along our territorial waters, who specializes in stealing, illegal refining and transporting of Nigeria's crude oil to the international black market. Similarly Vidal (2013) stated that some Niger Delta communities freely admit their role in the theft of oil but blame continuing poverty and pollution for their actions. "The government and oil companies are collecting our oil and we don't have jobs or money so we have to collect the oil and refine our own", says a man in the village of Bolo near where an illegal refinery was set up. Apparently, due to joblessness and poverty, the Niger Delta youth see illegal oil bunkering as a legitimate business.

\section{The Socio-Economic and Environmental Impacts of Oil Theft}

Oil theft and illegal bunkering activities leads to loss of revenues to the Nigerian Government and the oil firms that own the assets from which oil is stolen, pipeline vandalism, river and land pollution, environmental degradation , increased criminality and insecurity in the Niger Delta region. Consequently, hereunder is a discussion on the major impacts of oil theft using the following sub-heads:

Socio-Economic Losses to the Nigerian State: Oil theft has been identified as the biggest threat to Nigeria's economy. Its socio-economic impacts include environmental degradation, loss of economic activities for the communities, loss of revenues to the government resulting in inadequate funding for development initiatives, increased criminality in Niger Delta region, lack of security due to illegal activities and infiltration of international collaborator and bad image for the country (Duru, 2013; Okere, 2013). As a result of crude oil theft, maintenance of oil terminals and declaration of force majeure, the money shared by the three tiers of government in Nigeria in 2013 was erratic. In the first quarter of 2013 alone, Nigeria lost about N191 billion (\$1.23 billion) due to drop in crude oil production, arising from incessant crude oil theft and vandalism along the major pipelines within the Niger Delta, the Nigerian National Petroleum Corporation (NNPC) disclosed. Daily crude oil production during the period fluctuated between 2.1 and 2.3 million barrels per day (mbpd) compared with the projected estimate of $2.48 \mathrm{mbpd}$. Expectedly, the fall between actual production and forecast in first quarter of 2013 resulted in a drop in crude oil revenue of about $\$ 1.23$ billion (N191 billion) that should have accrued to the Federation Account (Mernyi, 2014).

Also, due to the loss of oil revenue to the oil thieves, Nigeria can no longer export crude oil above two million barrels per day as opposed to budgetary provision of 2.5 million barrels per day (Olateju, 2013). Nigeria is no longer selling enough crude oil to meet budgetary provisions. The government is failing to meet some of its obligation and domestic debt is rising rapidly. For instance, the country targeted, according to its financial plans for the year 2013, 2.53 million barrels per day production, a projection it failed to meet due to oil theft. Ogbeifun (2014) noted that the negative impacts of vandalism and crude oil theft include the destruction of aquatic and farmlands, economic sabotage which explains the shortfall of Nigeria's 2014 budget from $\$ 29.3$ billion in 2013 to $\$ 23.3$ billion in 2014 and divestments by some International Oil Companies, IOCs, with attendant job losses thereby compounding the unemployment situation in Nigeria. The colossal lost of revenue to oil theft was succinctly captured by Gaskia (2013). He aptly stated that:

\footnotetext{
"Over the past 3 to 6 years, in particular since the commencement of the presidential Amnesty programme for the Niger Delta, the subsequent inducement of a reduction in armed militancy in the region, and the consequent rise in the incidences of crude oil theft, we have been told by the highest responsible authorities (NNPC, Ministers of Finance and Petroleum Resources, CBN Governor etc) that the country has been losing outrageous quantities of crude oil to oil theft and pipeline vandalism. In 2009 and 2010, the figures claimed ranged from 100,000 barrels per day to 200, 000 barrels per day of crude oil. By 2012 this figure had risen to between 200,000 and 300,000 barrels per day of crude oil and now the figure given for 2013 is 400,000 barrels per day of crude oil lost to oil theft. This represent between $20 \%$ and $25 \%$ of our total daily production capacity of between 2 and 2.5 million barrels per day of crude oil. It also amount to an annual revenue losses of about $\$ 14$ billion i.e., \#2.24 trillion, that is almost half (50\%) of the annual federal government budget. This is a colossal loss by any standards".
} 
The Nigerian National Petroleum Corporation (NNPC) also disclosed that the federal government lost over \$11billion (about N1.72trillion) worth of oil revenue in 2013. The former group managing director of the corporation, Andrew Yakubu, who gave the figure, attributed the loss to incessant attacks on major pipelines and crude oil theft in the Niger Delta (Izuora, 2014). Similarly, the Coordinating Minister of the Economy and Minister of Finance, Mrs. Ngozi Okonjo-Iweala said that in 2013 crude oil theft and associated deferred production was estimated at over 300,000bpd. This costs the Nigerian government some $\$ 12$ billion annually in terms of deferred production revenues and the cost of pipeline repairs (Igbuku, 2014). Although, these figures of oil theft and illegal bunkering are not premised on any empirically verifiable statistics of Nigeria's oil production, nevertheless the figures are mindboggling. Despite the different estimates quoted by different authorities, what we can draw is that the volume of stolen oil in the Niger Delta region of Nigeria is enormous and these have significant adverse impact on socio-economic development of Nigeria.

Environmental Pollution and Degradation in the Niger Delta Region: The process of breaking and tapping oil from oil installations may lead to the damage of oil pipelines; it causes many leaks that cause immense environmental degradation. Crude oil theft involves breaking of pipelines and siphoning of crude oil products. This act invariably leads to oil facilities damages and oil spillage. Oil spillage causes degradation of the environment; it destroys farms lands and forests thereby reducing arable land for farming. Spills into water ways destroy marine and aquatic life, flora, fauna, resort centers and result in the pollution of potable water (Badejo and Nwilo 2007). Oil theft activities and pipeline vandalism in the Niger Delta compounds oil spillages from other sources and exacerbates the problem of environmental degradation and pollution of water-ways (Ogbuefin, 2007). Crude oil theft is responsible for a large percentage of oil spills. Oil spills result in ground water poisoning, destruction of agricultural land, fishery and livestock and fast disappearing mangrove forests. Worse, the illegal oil refineries that dot the oil rich Niger Delta see oil spilled everywhere soaking the ground with a mix of mud and crude that swallows the leg up to the knees. Many people in the Niger Delta region have complained that water from freshly sunk boreholes show evidence of oil contamination. This makes the water undrinkable even after some treatment. Also, some native have been known to use or drink polluted water out of frustration and the negative effects cannot be over emphasized ( Ufford, 2013; Alawode \& Ogunleye, 2013). In fact, farmland, fish ponds, rivers, etc., have been destroyed and rendered unviable for agriculture, fisheries and aquaculture. Thus, thousands of household and families of the Niger Delta have been impoverished, or have became securely locked into poverty as a result of this scale of environmental devastation (Gaskia, 2013). This devastation has left many Niger Delta communities further impoverished since their means of livelihood, fishing and farming, have been ruined by constant spills and leakages.

Economic losses to the International Oil Companies: Attacks on oil production facilities have led to several shutdowns and declaration of force majeure by the International Oil Companies (IOCs), ultimately resulting in loss of revenue to the oil companies as well as the government (Alohan, 2013). The activities of oil thieves in the Niger Delta has led to several shut-ins and shut-downs of pipelines and crude oil production respectively by international oil companies and thus resulted in decline in production capacity as well as loses of revenues to the companies. Force majeure is a legal clause that allows a company to walk away from a supply contract - owing to theft and sabotage. International oil companies (IOCs) operating in Nigeria are counting heavy losses as surge in crude oil theft and supply disruption have impacted on their earnings (Asu, 2013). For instance in September 23, 2013 Shell (Nigeria's Biggest International Oil Company) had to close its trans-Niger pipeline, which should carry 150,000 barrels per day because of leaks due to theft, less than a week after it had been reopened. In the process of oil theft, pipelines are vandalized and oil is spilled. Consequently, there will be urgent need by the oil companies to repair the pipelines and clean up of oil spills in the environment and this involve huge capital expenditure and it invariably leads to lose of revenues to the oil companies. The money that could have been spent on other areas of oil exploration and production are (now) used for pipeline repair, maintenance and cleaning oil spills (Alawode \& Ogunleye, 2013).

Shell Petroleum Development Corporation (SPDC) has consistently declared force majeure on its operations, from 2009, 2010, 2011, 2.012 and 2013. This was due to the activities of oil thieves who had damage its pipeline thus disrupting production. Nigeria Agip Oil Company (NAOC) in September 2013 declared a force majeure regarding crude oil lifting at the Brass Terminal and suspended its activities in Bayelsa State, following the intensification of illegal bunkering activities and the vandalisation of the 10-inch Kwale-Akri-Nembe-Brass oil delivery line. In April, 2013, Shell; shut-down the 150,000 barrels per day Nembe Creek oil pipeline due to the urgent need to clear away illegal connections (Alohan, 2013). Another explosion and fire at a crude theft point on Shell's facility at Bodo West in Ogoniland also forced the company to shut the Trans Niger Pipeline (TNP), in June 2013, deferring some 150,000 barrels of oil per day (bpd). Shell shut down again Trans Niger pipeline that produces 150,000 barrels per day on July 16, 2013 due to leakage from vandalism by oil theft. Shell shut down again the 150,000 barrels per day at the Trans Niger pipeline on $16^{\text {th }}$ September, 2013 barely a week after it reopened the facility. Another shut-in occurred on Wednesday September 18, 2013 following reports of a leaking crude theft point at Bodo west in Ogoniland. Shell declared force majeure on Bonny light exports on 
October 10, 2013 due to increase crude oil theft resulting in 300,000 barrels shut in from two key pipelines- Trans Niger pipeline (TNP) at B-Dere, Nonwa-Tai and Bodo west (Olusola, 2013; Bello, 2013). The frequent illegal tapping of pipelines is often very crude and causes frequent pipeline leaks. This forces oil companies to shutdown production while crucial repairs are conducted (Sun, 2013). A total of 189 crude theft points were repaired on the Trans Niger pipeline (TNP) and Nembe Creek Trunkline (NCTL) between January and September 2013 due to oil theft (Bello, 2013).

Insecurity in the Niger Delta Region-Threat to National and Regional Peace and Security: The damage caused by oil thieves often force oil companies to shut pipelines down. As a result, Nigeria is producing oil at 2.0 million barrels per day below its capacity of 2.5 million barrels per day (Olateju, 2013). This is a serious threat to national security particularly as Nigeria depends heavily on oil exports for survival. Apart from its economic loss, negation of investment onshore exploration and production, security risks and damage to equipment, illegal oil bunkering fuels conflict and militancy through increased armed proliferations and drug abuse which have destabilized the Niger Delta region (Garuba, 2010). Katsouris and Sayne (2013) noted that oil theft has been the major cause of violent conflict in the Niger Delta. Most of the oil theft actors exchange the crude oil for heavy arms at the high sea, while others use the proceeds to import arms into the region, with the principal aim of using the arms to secure their illegal activities in the region. The arms are used for attacks and counter attacks from different gang groups and security agents, as every group is bound to have adequate arms and be gun-battle ready to enable them remain in the business. This has resulted in proliferation of small and heavy arms in the region, leading to constant attacks and counter attacks by different groups, and insecurity of lives and properties in the region (Wilson, 2014). In same vein, Onwuemenyi (2012) posit that:

\begin{abstract}
"Many of the arms in circulation in the Niger Delta, including a variety of sophisticated weapons, have been purchased with money derived directly or indirectly from illegal bunkering. Adding that insecurity in some parts of the country results in part, from accessibility of oil-purchased arms with illegal bunkering serving as a major contributor to Nigeria's violent crime, armed robbery, piracy and kidnapping".
\end{abstract}

The trade in stolen oil helps other transitional criminal networks to spread across the Gulf of Guinea, creating global links between oil thieves, pirates and traffickers in arms and drugs. Wilson (2014) noted that the violence and crisis occasioned by the oil theft activities in the Niger Delta region is spreading speedily to other parts of Nigeria and beyond. Firstly, with the heavy arms in the possession of the youths and the constant attacks on oil and non oil facilities for economic benefits of the actors, youths from other geo-political regions see the oil theft activities as very lucrative and are recruited into oil theft activities as a means of economic empowerment. The same youths irrespective of geo-political region of origin are empowered with heavy arms and they use same to cause violence in different parts of the country, they are also sometimes used by the politicians to either attack political opponents or rig elections, thereby increasing the insecurity challenge of the nation. Secondly, larger part of the oil theft is carried out in the high seas and oil export terminals, thereby increasing the activities of the sea pirates in the sub-region (Wilson, 2014).

The pirates attack oil investors and their investments, while the state security agents give counter attack to the pirates, thereby leading to constant violence and attacks in the West African waterways. This violence perpetuated by the oil theft actors and sea pirates is threatening the peace and security of the West African States, particularly those along the coastal areas, where the oil vessels pass through to Europe, America and Asia (Wilson, 2014). Oil is the major catalyst that derives the Nigerian economy and by implication the determinant of its entire socio-political configuration. Consequently, anything that covertly or overtly affects oil production in Nigeria poses a direct threat to her national economy, political stability, territorial integrity and national security.

\title{
10. The Efforts of Nigerian Government to Curb Oil Theft
}

The successive Nigerian governments have undertaken some policy measures in responses to tackling the menace of oil theft over the years. The Government has sought to address escalating oil theft through the establishment of a task force on national strategic infrastructure intended to monitor and respond to oil theft, the establishment of a special security outfit and militarization of the Niger Delta region, increased enforcement measures against the maritime trade in stolen oil which involved the Nigerian Navy being tasked with the responsibility for registration of vessels in Nigerian waters, closing markets for illegal oil, a hotline for reporting oil theft, introduction of the Nigerian Extractive Industries Transparency Initiative, enforcement and public education efforts against artisanal refining and granting of amnesty to Niger Delta militants.

Illegal oil bunkering flourished during the military administration in Nigeria till 1999 when the civilian government took over the administration of the country. Worried about the rising incidents of illegal oil bunkering in Nigeria, Obasanjo 
administration particularly in the second tenure that began in 2003 took drastic measures to address the menace of illegal bunkering. A number of ships involved in the illegal trade in crude oil in Nigeria were seized and the perpetrators were arrested. However the seizure of ships and arrests of oil thieves did not lead to successful prosecutions due to the disappearance of seized ships and those involved in the acts. In order to put a stop to oil theft and illegal bunkering, the Nigerian government increased its military presence in the Niger Delta in 2003; this culminated in the deployment of a Joint Task Force (JTF) in 2008 (Tomas, 2010). The Joint Task Force comprises the Army, Navy, and paramilitary agencies. The JTF is mandated to curb and possible put an end to illegal bunkering in the oil-rich Niger Delta region. Since its establishment, the Joint Task Force has on several occasions launched offensive operations on the oil thieves. The outfit has paraded several suspected oil thieves and operators of illegal refineries in the creeks of Niger Delta leading to the destruction or recovery of several barges, canoes, speed and large wooden boats (Ogodo, 2012). Despite the JTF activities in the region, oil theft remained unabated. This shows that establishment of the JTF had not achieved the desired results of curtailing the upsurge of oil theft and illegal bunkering in the Niger Delta.

The Nigeria Government during the Obasanjo's administration, made attempts to close off the Ivory Coast refining of crude oil stolen from Nigeria, by putting in place a contract for supply of oil to the state owned refinery. It issued a warning to Cote d'Ivore in 2003 and offered the government contracts for the supply of legal oil to the state owned refinery. The Nigerian government also warned governments known to receive stolen oil from Nigeria to stop accepting it. However, this measure could have been effective if it has been applied to other nations known to be receiving Nigerian stolen oil.

During the president Yar Adua administration (2007-2009), the attacks on oil installations, kidnapping of oil workers by the militants and illegal oil bunkering became escalated further. In a bid to curb oil theft and other vices in the Niger Delta, former late President Yar Adua initiated the Amnesty programme to the Niger Delta militant. However, the demise of Yar 'Adua in 2009, his deputy Dr. Goodluck Jonathan took over the mantle of leadership. President Goodluck Jonathan has also responded in different ways to quell the menace of oil theft. He authorized the Nigeria Security and Civil Defence Corps (NSCDC) to carry arms and assigned greater roles, including protection of pipelines across the country. The president has also reached out to some of his counterparts in various countries where government feels some of Nigeria's crude are being refined in, and where these entities are laundering the funds made as a result of illegal bunkering (Nwanosike, 2013; Udo, 2013). President Goodluck Jonathan earlier in the 2014 approached the European Union and the United States for support by not purchasing stolen crude oil from Nigeria (Dodondawa, 2014).

The Federal Government had also engaged the services of some ex-militant leaders in the Niger Delta to patrol the country's vast coastline and protect her strategic oil installations but all these measures have not yielded a remarkable positive result. There are fears among stakeholders and security experts in the industry that crude oil theft in Nigeria may persist for long time to come due to level of sophistication the illicit trade has assumed in recent times and the caliber of persons involved in it even from within and outside the country (Uwotu, 2013).

\section{Measures to Curb Oil Theft: Is There A Way Out?}

The upsurge of oil theft requires multilateral and concerted efforts to address the problem. All stakeholders in the oil industry, the oil communities, and security forces should be involved in resolving the menace. In support of the above, the chief of Naval Staff, Nigerian Navy stressed that" the fight against crude oil theft and pipeline vandalism is a collective responsibility and no security agency can do it alone, as a way forward, oil majors should adopt the use of technology to secure the integrity of their pipelines and should also establish Rights of Way (RoW) for their pipelines to enable security officials to easily identify areas where there are breaches." He further advocated for constant review of corporate social responsibilities of oil major to host communities and improve opportunities for the restive youths as well as massive environmental resuscitation and crude oil products availability to the people of Niger Delta in order to give them a sense of belonging (Adeboboye, 2013; Duru, 2013; Ogodo, 2013). Concerted action is urgently needed at the local, national, regional and international levels to address the menace of crude oil theft. Therefore, Nigeria government should collaborate with other countries and international communities suspected to be patronizing her stolen oil on new international laws to regulate the oil movement from one country to the other. The international financial flows and networks which profit from these activities need to be traced, understood and targeted. The Federal Government should demonstrate the political will to unmask the big fish in the business of oil theft and illegal bunkering, as well as prosecute and secure conviction to serve as deterrent to others (Garuba, 2013).

Furthermore, there should be increased funding and equipment of the Joint Task Force, the Navy, the Nigerian Security and Civil Defense Corp, the Nigeria Maritime Administration and Safety Agency and other security operatives working in the region by the Federal Government to enable them defeat oil theft. The government should also facilitate 
socio-economic development of the Niger Delta people as well as carry out intensive and extensive concerted campaign to curtail criminality and oil theft in the region. The federal government must proceed towards a speedy development of the Niger Delta region to pacify its inhabitants for the marginalization done them over the years. This can help to gradually 'heal their wounds'and move them to support the security agents in their quest to tackle illegal oil bunkering (Omoyibo and Osunde, 2014). Several reports indicates that many of the local people could not find legitimate work and therefore turned to illegal bunkering as their only alternative. Thus, to curb oil theft government and oil companies operating in the Niger Delta should endeavour to provide employment opportunities for the Niger Delta youths. The government should address the socio-economic foundation of illegal bunkering, through the attack on poverty and job creation targeted at the youths, who must be made to come out of the creeks (Sun,2013).

The Federal Government should promptly engage with multinational oil companies to work out and agree on modalities for installing meters at the wellheads, flow stations and export terminals with a view to ascertaining the quantity of oil the country produces to enable it appreciate a near accurate measure of what is lost to thieves and illegal bunkerers (Garuba, 2013). On the part of the international oil companies in curbing the menace of oil theft, they should provide first line of protection for their facilities. They should install meters at the point of production that would measure the quantity of oil produced. They should also improve corporate social responsibility in their areas of operations in terms of human capacity development. In addition, the oil companies should encase pipeline in a minimum depth to protect against vandalism and they should stop the degradation of farmlands and waters in order not to deprive Niger Deltans of their source of livelihood, they should establish joint mini-refineries to absorb illegal refineries and engage local communities and fund the immediate clean up of the Niger Delta.

On the other hand, the security agencies should be up to their strides against oil thieves and consistently work to identify and flush out the enemies within that may be sabotaging their efforts. There should be enhanced security sector collaboration with community participation, enhanced intelligence gathering system with advance electronic and community input and increase collaboration with the Federal Government in combating oil theft and illegal bunkering in the Niger Delta and the Gulf of Guinea. The only way out of this menace is to adopt all these measures outlined above by all the stakeholders involved in the oil sectors, and this would go a long way in putting an end to oil theft in the Niger Delta.

\section{Conclusion}

In this paper, an attempt has been made to examine the phenomenon of oil theft and illegal bunkering in the Niger Delta with a view to situating its causes, impacts and implications vis-a-vis Nigeria's economy, national and regional security. The increase of oil theft and illegal bunkering in the Niger Delta region is an economic crime against Nigerian state; it undermines development strategies and engenders social disorder. It constitutes serious economic, security and environmental challenges to the Nigerian state. The paper observed that the upsurge oil theft has resulted in economic losses by the Nigerian state and oil companies, environmental degradation, insecurity in the Niger Delta region and threat to national and regional security. The paper also explored the efforts of successive Nigerian governments to curb the menace and posited that success has not been achieved due to the enthroned corruption by Nigerian elites, high level of youth unemployment, institutional decay and dysfunctions, poor governance, ineffective and corrupt law enforcement agencies, international crime collaborations etc. To stop oil theft, the paper recommends some measures and posits that multidimensional approach and concerted efforts are needed to put an end to oil theft in Nigeria.

\section{References}

Adeboboye, T. (2013) How oil thieves wreak havoc on Niger Delta communities. The Sun. August 23.

Adegbite, I. ( 2013) Climate Change, Perennial Crude Oil Theft and the Quest for Sustainable Development in Nigeria, OIDA International Journal of SustainableDevelopment 06: 12.

Ailemen, T. (2013) EITI to help halt oil theft in Nigeria. Business Day. October 15

Ajulo, L. (2013) Nigeria: Minister Alleges Complicity of Foreigners in Oil Theft. Worldstage. October 27. Retrieved November 30, 2013 from http/www.worldstagegroup. com/worldstagenew/index

Ajani, J. (2013) Nigeria: Crude Oil Theft Doom Looms as Government Loses N365 Billion in July Vanguard, August 25.

Akpabio, E.M. \& Akpan, N. S (2010). Governance and Oil Politics in Nigeria's Niger Delta: The Question of Distributive Equity. Journal of Human Ecology 30 (2). Pp 111-121

Akpan, U. (2013) Indigenous Operators Express Worry as Cost of Oil Theft hits N15.66n. National Mirror, November 12.

Alawode, J. A \& Ogunleye, O.I. (2011) "Maintenance, Security, and Environmental Implications of Pipeline Damage and Ruptures in the Niger Delta Region" The Pacific Journal of Science and Technology. (12) 1.565-573 
Alohan, J. (2013) Crude Oil Theft: Act of Terrorism or Lack of Political will? leadership November 10, Retrieved December 30, 2013 from http/leadership.ng/news/10/1/13

Arinze, E.P. (2011), "the Impact of Oil Price on the Nigerian Economy". Journal of Research in National Development (9) 1, 211-215

Asuni, B. J. (2009) Blood Oil in the Niger Delta Special Report. Washington; United States Institute of Peace.www.usip.org

Asu, F. (2013) IOCs Count Losses in Nigeria Crude Oil Theft Surges. Business Day, August, 26.

Badejo, O. T \& Nwilo, P.C. (2007) "Impacts and Management of Oil Spill Pollution along the Nigeria Coastal Areas". Journal of Environmental Management and Safety.

Bello, O. (2013) When will Nigeria stop the crude oil theft? Businessday, October 17.

Brock,J. (2012). Rampant Oil Theft Ravages Nigeria's Delta. Chicago Tribune, June 4, p.67.

Coventry Cathedral (2009) The Potential for Peace and reconciliation in the Niger Delta. Coventry, Uk: ICR

Daily Independent (2012) Menace of Illegal Oil Bunkering. Daily Independent. Retrieved, November 27, 2013 from www.dailindependent. com/2012/07

Dalby, C. (2014) These are the 5 countries most plagued by oil theft. Oilprice.com, July 4. Retrieved August 28, 2014 from http://business.financialpost.com/2014/07/04/these-are-the-5-countries-most-plagued-by-oil-theft/

Dodondawa, T. (2014) Oil theft: Nigeria's \$20bn per annum cesspit. Nigerian Tribune, August 12. Retrieved August 20, 2014 from http://tribune.com.ng/ business/item/13099-oil-theft-nigerias-20bn-per-annum-cesspit

Duru, A. E. (2013) Addressing oil theft, illegal bunkering in Niger Delta. Daily Independent Retrieved November 29, 2013 from www.dailindependent.com/2013/11

Ekuerhare, B. (2002) Sustainable Development models for the Niger Delta Region. In P. I. Ozon-Ezor and U. Ukiwo (Eds.) The Niger Delta Development Commission: Towards a Blue Print. Port Harcourt: Centre for Advanced Social Sciences

Feyide, M.O. (1986), Oil in World Politics. The J.I.C. Taylor Memorial Lecture Series, Lagos: University of Lagos

Garuba, S.D, (2012) Global Roots of Local Theft: Niger Delta Oil and the International Dimension of Illegal Bunkering Operations in Nigeria. Unpublished P.hD Seminal Paper at the Dept of Political Science and Public Admin, University of Benin, Benin City.

Gaskia, J. (2013) Crude Oil theft, Organized Crime, The Niger Delta Environment and The National Economy. Sahara Reporter. August 19

Igbuku, A. (2014) Crude Oil Theft and Illegal Refining in the Niger Delta. Delta State Oil and Gas Stakeholders' Conference, Tuesday, April 15, 2014. Retrieved August 20, 2014 from http://reformeronline.com/crude-oil- theft-and- illegal-refining-in-the-niger-delta/

Ikelegbe, A. (2005). The Political Economy of Conflict in the Oil Rich Niger Delta Region of Nigeria, Nordic Journal of African Studies, 14, (2): 208-234.

Ikein A. (2009). The Potential Power of West African Oil to the Economics and Energy Security Interest of Euro- America in the 21st century. Journal of Sustainable Development in Africa, 10(4): 540-556.

IRIN (2013) Nigeria: Rising Niger Delta Oil Theft Threatens Security, IRIN News.

Ite, E. A. et al (2013) Petroleum Exploration and Production: Past and Present Environmental Issues in Nigeria's Niger Delta”. American Journal of Environmental Protection 1(4) 78-90

Isoun T. T. (2001). Environmental Challenges of the Niger Delta" in Ozon-Eson, P.I. \& Ukiwo U. (eds.) Challenges of the Niger Delta: Port Harcourt: Centre for Advanced Social Science (CASS)

Izeze, I. (2013) Crude Oil Theft: Now, That NNPC is Disputing Shell's 700 Million Claim? Sahara Reporters. August 19.

Izuora, C. (2014) Nigeria Lost N1.72trn To Oil Theft In 2013 - NNPC. Leadership Newspaper, March 19. Retrieved August 20 from http://leadership. ng/news/356877/nigeria-lost-n1-72trn-oil-theft-2013-nnpc

Katsouris, C. \& Sayne, A. (2013) Nigeria's Criminal Crude: International Options to Combat the Export of Stolen Oil. London: Chatham House.

Mernyi, D. (2014) Crude Oil Theft, Pipeline Vandalism Cross Over To 2014. The Sun, January 1. Retrieved February 28, 2014 from http://sunnewsonline. com/new/specials/abuja-metro/crude -oil-theft-pipeline- vandalism-cross-2014/

Nwachukwu, J. N. (2008). The Niger Delta Imbroglio: An Agitational Terrorism or a Strategic Confronattion. Babcock Journal of Management and Social Sciences vol. 6. No2

Nwanosike, S. (2013) illegal Oil Bunkering: Matters Arising. The Tide. Retrieved November 29, 2013 from www.thetide.com

Obaje, N.G. (2009) Geology and Mineral Resources in Nigeria. Berlin, London: Springer

Obi, C. \& Rustad, A. S. ( 2011) "Introduction: Petro-Violence in the Niger Delta-The Complex Politics of an Insurgency" Cyril Obi and Siri Aas Rustad (eds), Oil and Insurgency in the Niger Delta: Managing the complex Politics of Petro-Violence. London: Zed Books

Odemwingie, E \& Nda-Isaiah, J. (2013) Nigeria Loses 400,000 Barrels Daily To Crude Oil Theft-Sentate. Leadership, November 14.

Ogbeifun, B. (2014) Why Nigeria should not treat oil theft with kid gloves-Ogbeifun. Vanguard in Sweet Crude, January 7. Retrieved on July 15, 2014 from http://www.vanguardngr.com/2014 /01/nigeria-treat-oil-theft-kid-gloves- ogbeifun/

Ogodo, D. (2012) Oil Bunkering in the Niger Delta Nigeria's Oil \& Gas. Retrieved on December 7, 2013 from www.nigerianoilgas. com/oil.bunkering-in-the-niger-delta

Ogunmade, O.\& Uwaezuoke, O. (2013) Nigeria's Crude Oil Theft Reaches Industrial Scale. Thisday September 22, Retrieved November 30, 2013. From http/www.thisdaylive.com/ articles/159597

Ojo, G.U. (2010). Toward a Non-Oil Economy: Resolving the Resource Curse Crisis in Nigeria. In Ojo G.U. (ed.) Envisioning a PostEconomy Petroleum Nigeria: Leave Oil in the Soil, Benin City: Environmental Rights Action/Friends of the Earth Nigeria.

Okafor, C.(2013) OPTS Disputes Figures on Nigeria's Daily Crude Oil Theft. This Day Live. Retrieved December 29, 2013 from www.thisdaylive.com/articles 
Okere, R. (2013) Curtailing Oil Theft, Illegal Bunkering via Legislation. The Guardian August 21

Okoli, A. C. (2013) The Political Ecology of Niger Delta Crisis and Prospects of Lasting Peace in the Post-Amnesty Period, Global Journal of Human Social Science, Vol.13 Issue 3 Version1.0

Okurebia, S. \& Daniel, E. (2014) Management of Amnesty Programme for Sustainable Livelihood in the Niger-Delta Region of Nigeria:Challenges and Policy Action. Journal of Business and Management (IOSR-JBM) Volume 14, Issue 3, PP 36-42

Olateju, B, (2013) Bamidele Upfront: Oil Theft The Fleecing of Nigeria. Premium Times October 8.

Olusola, B. (2013) when will Nigeria stop the Crude Oil Theft business Day. October 17.

Omoyibo, K.U. \& Osunde, O. (2014) Political Economy Diagnosis of Crude Oil Theft in Nigeria: The Way Forward. Mediterranean Journal of Social Sciences, Vol. 5 No 2

Onwuemenyi, O. (2012) Oil bunkering undermining Nigerian economy. Vanguard Retrieved on November 29, 2013 from www.vanguardngr.com./2012/06.

Osuji, C.C. \& Onojake, C.M. (2004) "Trace Heavy Metals Associated with Crude Oil. A Case Study of Ebocha-8 Oil-Spill-Polluted Site in Niger Delta, Nigeria. Chemistry and Biodiversity, I (II) 1708-1715.

Oyadongha, S. (2013) JTF Intercepts 2 Vessels, arrest 26 Suspected Bunkerers. Vanguard. October 7.

Oyadongha, S. (2013) 2013: JTF killed 82 sea pirates, nabbed 1,857 crude oil thieves in N-Delta -Commander.Vanguard, December 27. http://www.vanguardngr.com/2013/12/2013-jtf-killed-82-sea-pirates- nabbed-1857-crude-oil-thieves-n-delta-commander

PM News (2013) Cameroonian, 11 Nigerians arrested for oil Theft. Pmnews August 26.

Smil, V. (2008). Oil: A Beginner's Guide. Oxford: One world Publications.

Sun, K. (2013) Oil Theft in Nigeria. Retrieved August 20, 2014 from http://www.ocnus.net /artman2/publish /Africa_8/Oil-Theft-inNigeria.shtml

This Day (2005) Navy Gets New Combat Boats. This Day, October 4.

Tomas, M. (2010) Militancy in the Niger Delta, University of Pittsburgh.

Tonwe, A. D. \& Aghedo, I. (2013) Amnest y for Sustainable Peace and Development in Nigeria's Niger Delta: Panacea or Palliative? Journal of Sustainable Development in Africa (Volume 15, No.5-6, 2013)

Udo, A. (2013) crude oil theft, others reduce money shared by governments to \#573 billion in November. Premium Times, December 13. Ufford, J. (2013) Niger Delta Environment Degradation: when oil theft, illegal bunkering take centre stage. Vanguard. September 3.

Ugwuanyi, E. (2013), Oil theft: Endless Search, for Solution the Nation March 26, P.17.

Uwotu, K . (2013) Does Nigerian Government Have the Political Will to Combat Oil Theft?. Retrieved August 28, 2014 from http://www. aan.network.org.

Vidal, J. (2013) €1bn a month: the spiralling cost of oil theft in Nigeria. The Observer October 6. Retrieved November 29, 2013 from www.observer.com.

Wikipedia (2013) Niger Delta, Retrieved on December 11, 2013 from www.wikipedia.org/wiki/ Niger Delta

Wilson, G. (2012) Militancy in the Niger Delta Region and its impact on Nigerian State. International Journal of Educational Development. Vol. 2, No. 1, March, pp.55-66.

Wilson, G. (2014) The Nigerian State and Oil Theft in the Niger Delta Region of Nigeria, Journal of Sustainable Development in Africa. Vol. 16, No.1,

Yergin, D. (2008), the Prize: The Epic Quest for Oil Money and Power. New York: Free Press

Young, E.M (2012) Food and Development, Abingdon, Oxon, Routledge 